Review: The Central Sudan

Author(s): F. R. C.

Review by: F. R. C.

Source: The Geographical Journal, Vol. 37, No. 5 (May, 1911), pp. 555-556

Published by: geographicalj

Stable URL: http://www.jstor.org/stable/1778285

Accessed: 18-04-2016 04:58 UTC

Your use of the JSTOR archive indicates your acceptance of the Terms \& Conditions of Use, available at

http://about.jstor.org/terms

JSTOR is a not-for-profit service that helps scholars, researchers, and students discover, use, and build upon a wide range of content in a trusted digital archive. We use information technology and tools to increase productivity and facilitate new forms of scholarship. For more information about JSTOR, please contact support@jstor.org.

The Royal Geographical Society (with the Institute of British Geographers), Wiley are collaborating with JSTOR to digitize, preserve and extend access to The Geographical Journal 
relations, the folklore, the customs, traditions, and other particulars regarding the Bushmen, the Hottentots, and the southern Bantus; that is to say, all the aboriginal elements south of the Zambezi. This arrangement is highly satisfactory, for it not only enables Dr. Theal to avoid his besetting sin-confusion of treatment-but also to deal adequately with the several sections. In such a wide field omissions and commissions were of course inevitable, and the wonder is that the author has managed to escape so many pitfalls. The chief drawback is perhaps the failure to notice the results of the latest research, such as Prof. Meinhof's view that the Bantus are a blend of Hamitic and Negro stock, as indeed has already been pointed out by this writer. Moreover, the identity of the Bushmen and Congo pygmies seems now disproved by Prof. Keith's recent researches. The statement that the Ama-Xosa folklore is of Hottentot origin, "not being current among pure Bantu elsewhere," is not correct, and in point of fact such tales are found widely diffused throughout Bantuland, and even beyond it in Yoruba and Mandingo lands. The question of arrested progress at puberty is raised, but scarcely dealt with adequately, and those who first advanced the theory are not mentioned. But these are trifles which detract little from the solid merits of this valuable work.

A. H. K.

\section{The Central Sudan,}

'From Hausaland to Egypt, through the Sudan.' By H. Karl W. Kumm, PH.D. Maps and Illustrations. London: Constable \& Co., Ltd. 1910. 16s. net.

'Khont-Hon-Nofer. The Lands of Ethiopia.' By H. K. W. Kumm. Illustrations. London and Edinburgh: Marshall Bros., Ltd. 1910. $6 s$.

The first named of Dr. Karl Kumm's two books is mainly a narrative of his journey (made in 1908-09) from the Niger at Lokoja to Wau in the Bahr el Ghazal province. Until he reached Fort Archambault on the Shari, he was going over ground fairly familiar. Thence Dr. Kumm went east to Ndele, and from that region entered the basin of the Kotto, the most northerly affluent of the Congo. Here he was in an unknown, or practically unknown, land; certainly the route he chose had not been previously traversed by a white man. Of this region we should have been glad to have had a more detailed account. It was, however, traversed in the height of the rainy season, and for a considerable distance it was uninhabited and food was unobtainable-facts which render difficult scientific observations. The topographical results obtained are shown clearly in the map, and it will be noted that, besides the Kotto, eighteen of its tributaries or sub-tributaries had to be crossed in a distance of about 150 miles. The country, under cultivation, should prove one of the best in French Equatorial Africa. Dr. Kumm brings out vividly the difficulties and dangers of this part of the journey, and he approves himself a capable leader of men. Yet his account of what he saw in Nigeria, in Adamawa, and in the Shari district is of more importance than the other parts of his book. There is a comparison of British, German, and French methods of administration worthy of the attention of the governments concerned. The description of the Senussite sultanate of Ndele is excellent, and contains information not hitherto readily accessible. The book may also be recommended to the sportsman, who will find the author's record of his big-game hunting informative. From this it appears that elephants are very numerous in the lower Shari valley. In appendices Dr. Kumm deals with folk-lore and vocabularies, African outfits, meteorology, and with the zoological specimens brought home by the expedition. These included numerous 
butterflies, of which four fine coloured plates are given. The illustrations generally are good; the index is somewhat elementary.

One chapter of "From Hausaland to Egypt" is devoted to what is called the Moslem Peril, a theme developed in the second of Dr. Kumm's books. A Protestant missionary whose sphere of activity seeks to cover the whole Sudan, the author views with alarm the quasi-encouragement given by the British and German administrations in the Sudan to the spread of Islam. In the Shari territory, it seems, France prefers pagans to Moslems; but that is not the case, we believe, in the Western Sudan. 'Khont-Hon-Nofer' is welcome as ventilating a subject of vast consequence. The broad belt of country between Lake Chad and the Bahr-el-Ghazal is now predominantly pagan, but cannot so remain. It will become eventually Christian or Moslem, and on the issue depends the line of development of a considerable part of Africa. The question is not one simply of theological beliefs; it is also of profound social and political importance. Dr. Kumm puts his case clearly, and he does well to include an account of the Christian kingdoms of Nubia, where among a Negroid people Christianity persisted for over eight centuries. The book contains a useful bibliography.

F. R. C.

'Nigeria and its Tin Fields.' By Albert F. Calvert. (London: Edward Stanford. 1910. 3s. 6d.) Tin was first discovered (by white men) in Nigeria in 1884, and in 1905 its value was patent to the Niger Company at least. It was not, however, till the autumn of 1909 that the "boom" began. Since then over $£ 1,000,000$ has been invested in companies formed to exploit the fields. They are situated in the Bauchi province, and of their extent and value there is no longer room for doubt. So little definite information about the mining area has been available to the general public that $\mathrm{Mr}$. Calvert's book is welcome. Despite the indication in his preface, he has, however, little to say about Nigeria generally ; it is nearly all "tin." Mr. Calvert appears not to know that the Baro-Kano railway was undertaken through the efforts of Sir F. D. Lugard, though its construction was begun by Sir Percy Girouard. The inaccessibility of the tin-fields, to which Mr. Calvert draws attention, is about to be remedied, as the Colonial Office has now agreed to build a branch line to Bauchi. A word of praise is due to the illustrations; they number 259, andunlike the text-deal with all aspects of Nigeria, persons, places, and things.

'Islam Lands.' By Michael Myers Shoemaker. (New York and London: G. P. Putnam's Sons. 1910. Illustrations. 10s. 6d. net.) This is the latest in a lengthening list of travel books from the pen of an American writer who has had the fortune to visit many countries and who possesses the knack of describing what he has seen in a very taking manner. The sub-title of this particular volume-'Nubia, the Sudan, Tunisia, and Algeria'-sufficiently indicates the ground covered. Mr. Shoemaker gives just the information that the ordinary tourist seeks, and his pen pictures convey a pleasing sense of colour, space, and sunshine. He is apparently most interested in the Anglo-Egyptian Sudan and is fascinated by the story of Gordon. There is in his pages a good deal of gossip about Slatin Pasha and others which seems somewhat too frank, but it is all good natured. Like Mr. Roosevelt, he is struck with the good work England is doing in the Sudan, but he thinks that in Egypt the English are wrong in drawing (as he alleges) a colour bar against educated Egyptians. The account of the motor tour through Tunisia and Algeria is well told, and gives rise to warm tributes to the French administration, and to comparisons not favourable to American methods. 